\title{
Growth and mineral nutrition of baru (Dipteryx alata Vogel) in nutrient solution
}

\author{
Diana S. N. da Silva ${ }^{1}$, Nelson Venturin ${ }^{1}$, Cleber L. Rodas ${ }^{2}$, \\ Renato L. G. Macedo ${ }^{1}$, Regis P. Venturin ${ }^{3} \&$ Lucas A. de Melo \\ ${ }^{1}$ Universidade Federal de Lavras/Departamento de Ciências Florestais/Programa de Pós-Graduação em Engenharia Florestal. Lavras, MG. E-mail: \\ disuzete@yahoo.com.br (Corresponding author); venturin@dcf.ufla.br; rlgrisi@dcf.ufla.br; lucas.amaral@dcf.ufla.br \\ ${ }^{2}$ Universidade Federal de Lavras/Departamento de Ciência do Solo/Programa de Pós-Graduação em Ciência do Solo. Lavras, MG. E-mail: \\ cleberrodas@yahoo.com.br \\ ${ }^{3}$ Empresa de Pesquisa Agropecuária de Minas Gerais. Lavras, MG. E-mail: regis@epamig.br
}

Key words:

native forest species

hydroponics

lacking nutrient technique

\begin{abstract}
A B S T R A C T
This study analyzed the initial growth of baru in nutrient solutions with individualized omission of mineral nutrients in greenhouse. The experimental design was completely randomized with 13 treatments and four replicates: Complete Hoagland \& Arnon solution and with individualized omissions of $\mathrm{N}, \mathrm{P}, \mathrm{K}, \mathrm{Ca}, \mathrm{Mg}, \mathrm{S}, \mathrm{B}, \mathrm{Cu}, \mathrm{Fe}, \mathrm{Mn}, \mathrm{Mo}$ and $\mathrm{Zn}$. At 60 days the following morphological characteristics were evaluated: height, root collar diameter, number of leaves and number of leaflets. In addition, the Dickson quality index and root/shoot ratio were calculated and root dry matter, shoot dry matter and the contents and accumulations of nutrients in the shoots of the seedlings were analyzed. Analysis of variance of the collected data was performed using the computational program Sisvar. The growth of baru seedlings, except for the variable height, was influenced by the omission of nutrients in the nutrient solution and the main limiting nutrients are $\mathrm{K}, \mathrm{Ca}, \mathrm{Mg}, \mathrm{Fe}, \mathrm{Mn}$, and Mo. The absorption of nutrients by baru plants occurs differently under the individualized nutritional omissions applied to the nutrient solution.
\end{abstract}

\section{Palavras-chave:}

espécie florestal nativa

hidroponia

técnica do nutriente faltante

\section{Crescimento e nutrição mineral do baru (Dipteryx alata Vogel) em solução nutritiva}

\section{R E S U M O}

Analisou-se, neste trabalho, o crescimento inicial do baru em solução nutritiva com omissão individualizada dos nutrientes minerais em casa de vegetação. O delineamento experimental utilizado foi o inteiramente casualizado com 13 tratamentos e quatro repetições, sendo: Solução Hoagland \& Arnon completa e omissões individualizadas de N, P, K, Ca, Mg, S, B, Cu, Fe, Mn, Mo e Zn. Avaliaram-se, aos 60 dias após, a instalação do experimento, características morfológicas: altura, diâmetro do coleto, número de folhas e de folíolos. Foram calculados o índice de Dickson e a relação da massa seca da raiz/massa seca da parte aérea. A massa seca das raízes e da parte aérea foi determinada e analisados os teores e acúmulo de nutrientes na parte aérea das mudas. Realizou-se a análise de variância dos dados coletados por meio do programa computacional Sisvar. O crescimento de mudas de baru, com exceção da variável altura, foi influenciado pela omissão de nutrientes na solução nutritiva sendo os principais nutrientes limitantes o $\mathrm{K}, \mathrm{Ca}, \mathrm{Mg}, \mathrm{Fe}, \mathrm{Mn}$ e $\mathrm{Mo}$. A absorção dos nutrientes pelo baru ocorre de forma diferenciada em função das omissões nutricionais individualizadas aplicadas à solução de cultivo. 


\section{INTRODUCTION}

The devastation of the Brazilian Cerrado started in the 1960s, resulting in the alteration of its biodiversity (Machado et al., 2014). Initiatives must be promoted in order to avoid the loss of this valuable biodiversity and make viable the use of the biome (Davide \& Silva, 2008).

One of the limiting factors related to the production of seedlings of this species is the lack of knowledge on its nutritional requirements, which can compromise the success of projects of reforestation and recomposition of native areas (Sorreano et al., 2012). In addition, the nutritional requirement of each crop must be considered in order to improve the precision in fertilization management (Aquino et al., 2013).

The cultivation in nutrient solution consists in the conduction of crops without the use of soil, substituted by water, which transports the nutrients into the plants (Aprígio et al., 2012). Studies on the production of seedlings in nutrient solution and in controlled environments have been prioritized in detriment of experiments using other substrates (Marques et al., 2004; Sorreano et al., 2011). The adoption of the technique of cultivation in nutrient solution is justified by: the great flexibility for allowing monitoring and controlling the concentration of nutrients and gas around the roots almost in real time; the composition of the nutrient solution that surrounds the roots is known in quantitative terms; homogeneity in the composition of the solution of the rhizosphere in relation to the rest of the solution (Epstein \& Bloom, 2006). In spite of that, the applied amounts of water and nutrients do not always meet the water and nutritional requirements of the crops (Dantas Neto et al., 2013).

Baru (Dipteryx alata Vog.) is a species native to areas of Brazilian savanna (Cerrado) (Ajalla et al., 2012; Magalhães, 2014) and stands out for having potential for multiple uses (food, wood, landscaping, recovery of degraded areas and enrichment planting in pastures) (Martinotto et al., 2012). For this species, as well as for most species native to the Cerrado, little is known about the nutritional requirements (Carlos et al., 2014).

Thus, this study aimed to analyze the growth and nutrition of baru (Dipteryx alata Vog.) seedlings in nutrient solution with individualized omission of mineral nutrients in greenhouse.

\section{Material AND Methods}

The experiment was carried out in a greenhouse at the Forest Nursery of the Federal University of Lavras, in LavrasMG, Brazil (21 14' S; 44 00' W; 919 m). The baru seeds were collected in the region of Bom Jesus do Araguaia, MT, Brazil, and placed to germinate on a shallow tray ( $5 \mathrm{~cm}$ deep), covered with vermiculite and moistened with deionized water. These seeds are orthodox and their germination occurs between 7 and 14 days (Davide \& Silva 2008).

After reaching height of 5 to $10 \mathrm{~cm}$, at 45 days after sowing, the seedlings were cut in bare roots and transferred to a plastic tray containing $30 \mathrm{~L}$ of complete solution of Hoagland \& Arnon (1950), with constant aeration at the concentrations of 25,50 and $75 \%$ of its ionic force, remaining for 5 days at each concentration, according to the methodology used by Marques et al. (2004). After the adaptation period, the plants were individually planted in 5 -L plastic pots, with constant aeration, placed on a workbench. The seedlings were supported using 2-cm-thick polystyrene sheets.

The experimental design was completely randomized, with 13 treatments (complete nutrient solution of Hoagland \& Arnon and individualized omissions of $\mathrm{N}, \mathrm{P}, \mathrm{K}, \mathrm{Ca}, \mathrm{Mg}, \mathrm{S}, \mathrm{B}$, $\mathrm{Cu}, \mathrm{Fe}, \mathrm{Mn}, \mathrm{Mo}$ and $\mathrm{Zn}$ ), four replicates and one plant per plot.

The stock solutions of the nutrients were prepared using AR (analytical reagent) reagents and deionized water. Since baru is a slow-growing forest species and due to the use of a cultivation solution with high concentration of nutrients, this solution was renewed every 15 days (Epstein \& Bloom, 2006). In this interval of renewal, the volume of the pots was daily monitored and replenished always when necessary using deionized water.

At 60 after of experiment, the following biometric variables were determined: shoot height $(\mathrm{H})$, root collar diameter $(\mathrm{D})$, number of leaves (NL) and number of leaflets (NLf).

After the evaluations, the plants were harvested, separated into shoots and roots, washed in running water and in deionized water. Then, the plants were dried in a forced-air oven with temperature varying from 65 to $70^{\circ} \mathrm{C}$, until constant weight (Sorreano et al., 2011).

After drying, the material was weighed on a precision scale $(0.01 \mathrm{~g})$ to obtain shoot dry matter (SDM), root dry matter (RDM) and total dry matter (TDM). In addition, the root dry matter/shoot dry matter (R/S) ratio and the Dickson's quality index (DQI) (Dickson et al., 1960) were also calculated. DQI was obtained using the formula: DQI $=\mathrm{TDM}_{(\mathrm{g})} /\left[\left(\mathrm{H}_{(\mathrm{cm})} / \mathrm{D}_{(\mathrm{mm})}\right)\right.$ $\left.+\left(\mathrm{SDM}_{(\mathrm{g})} / \mathrm{RDM}_{(\mathrm{g})}\right)\right]$.

After weighing, the material of plant shoots was ground in a Wiley-type mill to be chemically analyzed (content and accumulation of nutrients), according to the Manual of Plant Mineral Nutrition (Malavolta, 2006).

The obtained data were subjected to analysis of variance and the means were compared by the Scott-Knott test at 0.05 significance level. The analyses were performed using the computational program Sisvar (Ferreira, 2011).

\section{Results AND Discussion}

The omissions of nutrients in the nutrient solution compromised the growth of baru plants and there was significant difference between the treatments for all analyzed variables, except for shoot height $(\mathrm{H})$ (Table 1).

Statistically $(p$-value $=0.052)$, there were no limitations to the growth of plants in height due to the omission of nutrients (Table 1), which can be explained by the moderate growth of the baru crop (Martinotto et al., 2012).

As to root collar diameter, the greatest restrictions to its growth were due to the deficiency of $\mathrm{P}, \mathrm{K}, \mathrm{Ca}, \mathrm{Mg}, \mathrm{B}, \mathrm{Cu}, \mathrm{Fe}$ and Mo. In the study of Mendonça et al. (1999), the absence of liming, $\mathrm{P}, \mathrm{Ca}, \mathrm{Mg}$, $\mathrm{K}$ and $\mathrm{B}$ promoted lower growth in diameter of Myracrodruon urundeuva. B was also the most limiting nutrient in a study conducted by Sorreano et al. (2008) with Croton urucurana plants.

There was a reduction of SDM and TDM in the treatments where $\mathrm{N}, \mathrm{K}, \mathrm{Ca}$ and $\mathrm{Fe}$ were removed. These elements 
Table 1. Shoot height $(\mathrm{H})$, root collar diameter $(\mathrm{D})$, shoot dry matter (SDM), root dry matter (RDM), total dry matter (TDM), root/shoot ratio (R/S), Dickson's quality index (DQI), number of leaves (NL) and number of leaflets (NLf) for seedlings of Dipteryx alata in nutrient solution

\begin{tabular}{|c|c|c|c|c|c|c|c|c|c|}
\hline Treatments & $\begin{array}{c}\mathrm{H} \\
(\mathrm{cm})\end{array}$ & $\begin{array}{c}\text { D } \\
(\mathrm{mm})\end{array}$ & SDM & $\begin{array}{c}\text { RDM } \\
\text { (g) }\end{array}$ & TDM & $R / S$ & DQI & NL & NLf \\
\hline Complete & $11.7 \mathrm{a}$ & $7.24 \mathrm{a}$ & $3.80 \mathrm{a}$ & $1.72 \mathrm{a}$ & $5.52 \mathrm{a}$ & $0.45 \mathrm{c}$ & $1.45 \mathrm{a}$ & $7.6 \mathrm{a}$ & $57.6 \mathrm{a}$ \\
\hline $\mathrm{N}$ & $9.7 \mathrm{a}$ & $6.29 \mathrm{~b}$ & $2.40 \mathrm{~b}$ & $2.04 \mathrm{a}$ & $4.45 b$ & $0.91 \mathrm{a}$ & $1.63 \mathrm{a}$ & $5.6 \mathrm{~b}$ & $40.6 \mathrm{~b}$ \\
\hline$P$ & $10.6 \mathrm{a}$ & $5.59 \mathrm{c}$ & $3.37 \mathrm{a}$ & $2.30 \mathrm{a}$ & $5.67 \mathrm{a}$ & $0.66 \mathrm{~b}$ & $1.69 \mathrm{a}$ & $6.3 \mathrm{~b}$ & $46.6 \mathrm{~b}$ \\
\hline K & $09.4 \mathrm{a}$ & $5.69 \mathrm{c}$ & $1.97 \mathrm{~b}$ & $0.92 b$ & $2.96 \mathrm{~b}$ & $0.46 \mathrm{c}$ & $0.78 \mathrm{~b}$ & $5.3 \mathrm{~b}$ & $36.0 \mathrm{~b}$ \\
\hline $\mathrm{Ca}$ & $08.5 \mathrm{a}$ & $5.26 \mathrm{C}$ & $1.81 \mathrm{~b}$ & $0.66 \mathrm{~b}$ & $2.47 \mathrm{~b}$ & $0.37 \mathrm{C}$ & $0.56 \mathrm{~b}$ & $6.0 \mathrm{~b}$ & $39.0 \mathrm{~b}$ \\
\hline $\mathrm{Mg}$ & $12.1 \mathrm{a}$ & $5.50 \mathrm{C}$ & $3.05 \mathrm{a}$ & $1.05 \mathrm{~b}$ & $4.10 \mathrm{~b}$ & $0.34 \mathrm{C}$ & $0.80 \mathrm{~b}$ & $5.3 \mathrm{~b}$ & $33.0 \mathrm{~b}$ \\
\hline S & $12.4 \mathrm{a}$ & $6.35 b$ & $4.15 \mathrm{a}$ & $1.73 \mathrm{a}$ & $5.88 \mathrm{a}$ & $0.41 \mathrm{C}$ & $1.35 \mathrm{a}$ & $7.6 \mathrm{a}$ & $52.6 \mathrm{a}$ \\
\hline B & $13.0 \mathrm{a}$ & $5.84 \mathrm{C}$ & $4.93 \mathrm{a}$ & $2.04 \mathrm{a}$ & $7.18 \mathrm{a}$ & $0.42 \mathrm{C}$ & $1.53 \mathrm{a}$ & $8.0 \mathrm{a}$ & $57.6 \mathrm{a}$ \\
\hline $\mathrm{Cu}$ & $11.4 \mathrm{a}$ & $5.89 \mathrm{c}$ & $3.46 \mathrm{a}$ & $1.47 \mathrm{~b}$ & $4.68 \mathrm{~b}$ & $0.45 \mathrm{c}$ & $1.13 \mathrm{~b}$ & $7.0 \mathrm{a}$ & $46.3 \mathrm{~b}$ \\
\hline $\mathrm{Fe}$ & $11.1 \mathrm{a}$ & $4.67 \mathrm{c}$ & $2.38 b$ & $1.44 \mathrm{~b}$ & $3.82 \mathrm{~b}$ & $0.60 \mathrm{~b}$ & $0.94 \mathrm{~b}$ & $6.3 \mathrm{~b}$ & $44.6 \mathrm{~b}$ \\
\hline $\mathrm{Mn}$ & $12.3 \mathrm{a}$ & $6.28 \mathrm{~b}$ & $4.20 \mathrm{a}$ & $1.41 \mathrm{~b}$ & $5.57 \mathrm{a}$ & $0.34 \mathrm{C}$ & $1.12 b$ & $8.0 \mathrm{a}$ & $57.0 \mathrm{a}$ \\
\hline Mo & $11.6 \mathrm{a}$ & $5.64 \mathrm{c}$ & $3.25 \mathrm{a}$ & $1.62 \mathrm{a}$ & $4.88 \mathrm{a}$ & $0.51 \mathrm{c}$ & $1.20 \mathrm{~b}$ & $7.6 \mathrm{a}$ & $51.6 \mathrm{a}$ \\
\hline $\mathrm{Zn}$ & $12.0 \mathrm{a}$ & $6.43 \mathrm{~b}$ & $3.81 \mathrm{a}$ & $2.03 \mathrm{a}$ & $5.88 \mathrm{a}$ & $0.53 \mathrm{C}$ & $1.53 \mathrm{a}$ & $7.3 \mathrm{a}$ & $52.0 \mathrm{a}$ \\
\hline CV (\%) & 16.53 & 9.21 & 29.78 & 30.34 & 29.01 & 19.76 & 28.92 & 14.9 & 17.91 \\
\hline
\end{tabular}

Means followed by different letters in the column differ by the Scott-Knott test at 0.05 probability level

directly influence the biomass produced by the plant. $\mathrm{N}$ and $\mathrm{K}$ are elements required in large amounts by most plants (Marschner, 2012) and are also observed in forest species, such as Eremanthus erythropappus (DC.) McLeish (Venturin et al., 2005). In Myracrodruon urundeuva plants, $\mathrm{N}$ and $\mathrm{K}$, followed by $\mathrm{Mg}$, proved to be highly limiting for the growth of seedlings (Mendonça et al., 1999).

As to RDM, there was a reduction in the treatments with omission of $\mathrm{Ca}, \mathrm{Mg}, \mathrm{K}, \mathrm{Cu}, \mathrm{Fe}$ and $\mathrm{Mn}$. The effect caused by the omission of Ca on root growth stands out (Malavolta, 2006; Marschner, 2012).

There was an increase in $\mathrm{R} / \mathrm{S}$ ratio with the omission of $\mathrm{N}$, $\mathrm{P}$ and $\mathrm{Fe}$, in relation to the complete treatment and the others, with an increment in the root system. Jones Júnior et al. (1991) report that plants can exhibit an increase in the root system as a mechanism to improve their access to $\mathrm{P}$ under deficient conditions of this nutrient, rapidly developing lateral roots rich in absorbent hairs.

The deficiencies of $\mathrm{P}, \mathrm{Mg}, \mathrm{S}, \mathrm{B}, \mathrm{Cu}, \mathrm{Mn}, \mathrm{Mo}$ and $\mathrm{Zn}$ did not cause reduction in SDM production, which is probably due to the fact that plants acquired a reserve of these nutrients during the phase of adaptation to the nutrient solution. Likewise, the treatments with omission of $\mathrm{P}, \mathrm{S}, \mathrm{B}, \mathrm{Mn}, \mathrm{Mo}$ and $\mathrm{Zn}$ also did not differ from the complete treatment with respect to TDM.

The Dickson's quality index (DQI) is widely used in the determination of seedlings quality. This index considers the interaction of various parameters that reflect the conditions of development of the plant (Rudek et al., 2013). The treatments with lowest DQI were those with absence of $\mathrm{Ca}, \mathrm{K}, \mathrm{Mg}, \mathrm{Fe}$, $\mathrm{Mn}, \mathrm{Cu}$ and Mo.

The lowest production of leaves was observed in the treatments with omission of $\mathrm{N}, \mathrm{P}, \mathrm{K}, \mathrm{Ca}, \mathrm{Mg}$ and $\mathrm{Fe}$, which differed from the others. The omissions of $\mathrm{N}, \mathrm{K}$ and $\mathrm{Mg}$ negatively influence the growth of this species regarding the number of leaves. Sorreano et al. (2011), in seedlings of Croton urucurana ('Sangra d'Água'), observed similar behavior with the suppression of $\mathrm{N}, \mathrm{Ca}$ and $\mathrm{Mg}$.

The lowest production of leaflets was observed in the treatments with absence of $\mathrm{Mg}, \mathrm{K}, \mathrm{Ca}, \mathrm{N}, \mathrm{Fe}, \mathrm{Cu}$ and $\mathrm{P}$, which differed from the others. Photosynthesis is a vital process for plants and occurs mainly in leaves and leaflets. Because of that, the reduction of these structures decreases their area and, consequently, the photosynthetic capacity, representing a barrier to the vegetative and reproductive development (Flumignan et al., 2008; Machado et al., 2010; Taiz \& Zeiger, 2013).

The external concentration of ions is one of the factors that affect the ionic absorption in the roots (Marschner, 2012). When each nutrient was separately omitted in the nutrient solution, there was a decrease of the respective contents in the plants (Table 2).

Jones Júnior et al. (1991) point out that, when $S$ becomes limiting, the $\mathrm{N}$ content tends to increase. However, the results demonstrate that, although there was a decrease in the $\mathrm{N}$ content in the baru plant under the omission of $\mathrm{S}$, the $\mathrm{N}$ accumulation did not differ from that in the complete treatment (Table 3). This occurred because the dry matter increased in this treatment, in relation to the complete treatment.

The total amount of nutrients in the plant increases with the age, but the concentration in a tissue can increase, decrease or remain unchanged, depending on the nutrient and tissue (Ramos et al., 2011).

In the absence of $\mathrm{P}$, there was a decrease in the $\mathrm{N}$ content (Table 2), with also a decrease of $\mathrm{P}$ in the omission of $\mathrm{N}$. Jones Júnior et al. (1991) observed this behavior in various plant species. According to these authors, the increase in $\mathrm{N}$ absorption causes an increment in $\mathrm{P}$ concentration in the solution, and $\mathrm{N}$ sources favor the transfer of $\mathrm{P}$ by the cell barriers during the absorption and movement of this nutrient through the xylem.

The omissions of $\mathrm{K}, \mathrm{Ca}$ and $\mathrm{Fe}$ led to increments in $\mathrm{N}$ contents in the shoots (Table 2). There was an effect of concentration, due to the low production of biomass in these treatments, in comparison to the complete treatment. Similar results were reported by Mendonça et al. (1999) and Marques et al. (2004) in the species 'aroeira-do-sertão' (Myracrodruon urundeuva) and 'paricá' (Schizolobium amazonicum), respectively.

The omission of $\mathrm{P}$ resulted in the reduction of $\mathrm{P}$ and $\mathrm{Ca}$ contents in the shoots, compared with the complete treatment 
Table 2. Dry matter production and contents of macronutrients in the shoots of Dipteryx alata plants under omission of macro and micronutrients

\begin{tabular}{|c|c|c|c|c|c|c|c|}
\hline \multirow{2}{*}{ Treatment } & \multirow{2}{*}{$\begin{array}{l}\text { Dry matter } \\
\text { (g) }\end{array}$} & \multicolumn{6}{|c|}{ Contents $\left(\mathrm{g} \mathrm{kg}^{-1}\right)$} \\
\hline & & $\mathrm{N}$ & $P$ & K & $\mathrm{Ca}$ & $\mathrm{Mg}$ & $S$ \\
\hline Complete & 3.80 & $31.45 b$ & $8.34 \mathrm{a}$ & $15.90 \mathrm{a}$ & $8.66 \mathrm{a}$ & $2.18 b$ & $4.21 \mathrm{a}$ \\
\hline $\mathrm{N}$ & 2.40 & $11.77 \mathrm{~d}$ & $4.51 \mathrm{~b}$ & $15.30 \mathrm{a}$ & $5.82 \mathrm{~b}$ & $2.39 \mathrm{a}$ & $2.79 \mathrm{c}$ \\
\hline $\mathrm{P}$ & 3.37 & $24.82 \mathrm{C}$ & $1.24 \mathrm{C}$ & $11.25 b$ & $4.31 \mathrm{c}$ & $1.44 \mathrm{C}$ & $2.42 \mathrm{c}$ \\
\hline K & 1.97 & $39.42 \mathrm{a}$ & $9.19 \mathrm{a}$ & $4.35 \mathrm{C}$ & $9.75 \mathrm{a}$ & $2.60 \mathrm{a}$ & $3.28 b$ \\
\hline $\mathrm{Ca}$ & 1.81 & $40.00 \mathrm{a}$ & $5.54 \mathrm{a}$ & $15.15 \mathrm{a}$ & $2.72 \mathrm{c}$ & $2.07 \mathrm{~b}$ & $3.14 b$ \\
\hline $\mathrm{Mg}$ & 3.05 & $32.67 \mathrm{~b}$ & $7.72 \mathrm{a}$ & $13.65 b$ & $6.32 \mathrm{~b}$ & $0.47 \mathrm{c}$ & $2.35 \mathrm{c}$ \\
\hline$S$ & 4.15 & $26.67 \mathrm{C}$ & $5.92 \mathrm{a}$ & $14.40 \mathrm{a}$ & $7.18 b$ & $1.69 \mathrm{c}$ & $2.27 \mathrm{c}$ \\
\hline B & 4.93 & $32.82 \mathrm{~b}$ & $6.69 \mathrm{a}$ & $14.55 \mathrm{a}$ & $6.37 \mathrm{~b}$ & $1.90 \mathrm{C}$ & $2.97 \mathrm{~b}$ \\
\hline $\mathrm{Cu}$ & 3.46 & $34.47 \mathrm{~b}$ & $6.76 \mathrm{a}$ & $12.90 \mathrm{~b}$ & $7.36 \mathrm{~b}$ & $1.92 \mathrm{C}$ & $3.42 \mathrm{~b}$ \\
\hline $\mathrm{Fe}$ & 2.38 & $38.27 \mathrm{a}$ & $7.02 \mathrm{a}$ & $16.05 \mathrm{a}$ & $7.04 \mathrm{~b}$ & $2.02 \mathrm{~b}$ & $3.80 \mathrm{a}$ \\
\hline $\mathrm{Mn}$ & 4.20 & $35.77 \mathrm{~b}$ & $7.14 \mathrm{a}$ & $15.15 \mathrm{a}$ & $6.20 \mathrm{~b}$ & $1.77 \mathrm{C}$ & $3.14 b$ \\
\hline Mo & 3.25 & $31.05 b$ & $6.85 \mathrm{a}$ & $13.65 b$ & $6.63 \mathrm{~b}$ & $1.47 \mathrm{C}$ & $3.32 b$ \\
\hline $\mathrm{Zn}$ & 3.81 & $34.60 \mathrm{~b}$ & $7.18 \mathrm{a}$ & $14.40 \mathrm{a}$ & $6.25 b$ & $2.04 \mathrm{~b}$ & $3.19 b$ \\
\hline CV $(\%)$ & & 13.70 & 25.24 & 10.48 & 20.89 & 16.04 & 15.47 \\
\hline
\end{tabular}

Means followed by the same letter in the column do not differ by the Scott-Knott test at 0.05 probability level

Table 3. Dry matter production and accumulation of macronutrients in the shoots of Dipteryx alata plants under omission of macro and micronutrients

\begin{tabular}{lccccccc}
\hline \multirow{2}{*}{ Treatment } & Dry matter & \multicolumn{5}{c}{ Accumulation (mg plant $^{-1}$ ) } \\
\cline { 3 - 7 } Complete & $(\mathbf{g})$ & $\mathbf{N}$ & $\mathbf{P}$ & $\mathbf{K}$ & $\mathbf{C a}$ & $\mathbf{M g}$ & $\mathbf{S}$ \\
$\mathrm{N}$ & 3.80 & $119.51 \mathrm{~b}$ & $31.69 \mathrm{a}$ & $60.42 \mathrm{a}$ & $32.91 \mathrm{a}$ & $8.28 \mathrm{a}$ & $15.99 \mathrm{a}$ \\
$\mathrm{P}$ & 2.40 & $28.24 \mathrm{~d}$ & $10.82 \mathrm{~d}$ & $36.72 \mathrm{~b}$ & $13.97 \mathrm{~b}$ & $5.74 \mathrm{~b}$ & $6.70 \mathrm{~b}$ \\
$\mathrm{~K}$ & 3.37 & $83.64 \mathrm{C}$ & $4.18 \mathrm{~d}$ & $37.91 \mathrm{~b}$ & $14.52 \mathrm{~b}$ & $4.85 \mathrm{~b}$ & $8.16 \mathrm{~b}$ \\
$\mathrm{Ca}$ & 1.97 & $77.65 \mathrm{C}$ & $18.10 \mathrm{c}$ & $8.57 \mathrm{C}$ & $19.21 \mathrm{~b}$ & $5.12 \mathrm{~b}$ & $6.46 \mathrm{~b}$ \\
$\mathrm{Mg}$ & 1.81 & $72.40 \mathrm{C}$ & $10.03 \mathrm{~d}$ & $27.42 \mathrm{~b}$ & $4.92 \mathrm{c}$ & $3.75 \mathrm{~b}$ & $5.68 \mathrm{~b}$ \\
$\mathrm{~S}$ & 3.05 & $99.64 \mathrm{C}$ & $23.55 \mathrm{~b}$ & $41.63 \mathrm{~b}$ & $19.28 \mathrm{~b}$ & $1.43 \mathrm{c}$ & $7.17 \mathrm{~b}$ \\
$\mathrm{~B}$ & 4.15 & $110.68 \mathrm{~b}$ & $24.57 \mathrm{~b}$ & $59.76 \mathrm{a}$ & $29.80 \mathrm{a}$ & $7.01 \mathrm{a}$ & $9.42 \mathrm{~b}$ \\
$\mathrm{Cu}$ & 4.93 & $161.80 \mathrm{a}$ & $32.98 \mathrm{a}$ & $71.73 \mathrm{a}$ & $31.40 \mathrm{a}$ & $9.37 \mathrm{a}$ & $14.64 \mathrm{a}$ \\
$\mathrm{Fe}$ & 3.46 & $119.26 \mathrm{~b}$ & $23.39 \mathrm{~b}$ & $44.63 \mathrm{~b}$ & $25.47 \mathrm{a}$ & $6.64 \mathrm{a}$ & $11.83 \mathrm{a}$ \\
$\mathrm{Mn}$ & 2.38 & $91.08 \mathrm{C}$ & $16.71 \mathrm{C}$ & $38.20 \mathrm{~b}$ & $16.76 \mathrm{~b}$ & $4.81 \mathrm{~b}$ & $9.04 \mathrm{a}$ \\
$\mathrm{Mo}$ & 4.20 & $150.23 \mathrm{a}$ & $29.99 \mathrm{a}$ & $63.63 \mathrm{a}$ & $26.04 \mathrm{a}$ & $7.43 \mathrm{a}$ & $13.19 \mathrm{a}$ \\
$\mathrm{Zn}$ & 3.25 & $100.91 \mathrm{C}$ & $22.26 \mathrm{~b}$ & $44.36 \mathrm{~b}$ & $21.55 \mathrm{a}$ & $4.78 \mathrm{~b}$ & $10.79 \mathrm{a}$ \\
$\mathrm{CV}(\%)$ & 3.81 & $131.82 \mathrm{~b}$ & $27.36 \mathrm{~b}$ & $54.86 \mathrm{a}$ & $23.81 \mathrm{a}$ & $7.77 \mathrm{a}$ & $12.15 \mathrm{a}$ \\
\hline
\end{tabular}

Means followed by the same letter in the column do not differ by the Scott-Knott test at 0.05 probability level

(Table 3). The omission of both $\mathrm{N}$ and $\mathrm{P}$ affected the behavior of $\mathrm{Ca}$, because the addition of $\mathrm{N}$ and $\mathrm{P}$ in the medium favors $\mathrm{Ca}$ accumulation in the leaves (Malavolta, 2006). Thus, the absence of these nutrients may have damaged the absorption of Ca by the plants.

The increase in Mg contents in the shoots was observed in the treatment with omission of $\mathrm{K}$ (Table 3 ) as a consequence of the competition between these nutrients. Some authors also report the effect of the competitive inhibition between $\mathrm{K}$ and $\mathrm{Mg}$ in plants of Myracrodruon urundeuva ('aroeira-do-sertão') (Mendonça et al., 1999) and Peltophorum dubium ('angico amarelo') (Venturin et al., 1999). According to Malavolta (2006), there is an antagonism between $\mathrm{Ca}, \mathrm{Mg}$ and $\mathrm{K}$, in which the increase in the concentration of one of these nutrients in the medium leads to the decrease in the absorption of the others, which justifies the high contents of $\mathrm{Mg}$ in the treatment with omission of $\mathrm{K}$.

The highest contents of S in the shoots were observed in the complete treatment and in the treatment with defficiency of Fe (Table 3). Similar result was found by Mendonça et al. (1999) in the species Myracrodruon urundeuva. According to Malavolta (2006), the sulfates are found in solution or in poorly soluble combinations with $\mathrm{Fe}$ and $\mathrm{Al}$, which explains the high content of $\mathrm{S}$ in the omission of Fe.
Analyzing the micronutrients only in the treatment with omission of $\mathrm{B}$, the content of this nutrient was statistically inferior to those of the other treatments (Table 4).

Except for the omissions of $\mathrm{K}, \mathrm{Fe}$ and $\mathrm{Mn}$, the other treatments showed reduction in the content of $\mathrm{Cu}$, compared with the complete treatment. Mendonça et al. (1999)

Table 4. Dry matter production and contents of micronutrients in the shoots of Dipteryx alata plants under omission of macro and micronutrients

\begin{tabular}{lcccccc}
\hline \multirow{2}{*}{ Treatment } & Dry matter & \multicolumn{5}{c}{ Contents $\left(\mathbf{m g ~ k g}^{-1}\right)$} \\
\cline { 3 - 7 } Complete & 3.80 & $39.01 \mathrm{a}$ & $4.11 \mathrm{a}$ & $183.21 \mathrm{C}$ & $87.42 \mathrm{~b}$ & $14.14 \mathrm{a}$ \\
$\mathrm{n}$ & 2.40 & $34.76 \mathrm{a}$ & $2.26 \mathrm{~d}$ & $108.30 \mathrm{~d}$ & $115.21 \mathrm{~b}$ & $11.34 \mathrm{a}$ \\
$\mathrm{P}$ & 3.37 & $29.11 \mathrm{a}$ & $2.71 \mathrm{c}$ & $184.15 \mathrm{C}$ & $70.07 \mathrm{~b}$ & $11.71 \mathrm{a}$ \\
$\mathrm{K}$ & 1.97 & $28.89 \mathrm{a}$ & $4.66 \mathrm{a}$ & $224.19 \mathrm{C}$ & $73.55 \mathrm{~b}$ & $17.07 \mathrm{a}$ \\
$\mathrm{Ca}$ & 1.81 & $33.70 \mathrm{a}$ & $3.71 \mathrm{~b}$ & $232.57 \mathrm{C}$ & $65.99 \mathrm{~b}$ & $15.75 \mathrm{a}$ \\
$\mathrm{Mg}$ & 3.05 & $32.82 \mathrm{a}$ & $3.55 \mathrm{~b}$ & $212.39 \mathrm{C}$ & $108.39 \mathrm{~b}$ & $18.45 \mathrm{a}$ \\
$\mathrm{S}$ & 4.15 & $34.58 \mathrm{a}$ & $3.38 \mathrm{~b}$ & $193.38 \mathrm{C}$ & $93.26 \mathrm{~b}$ & $14.70 \mathrm{a}$ \\
$\mathrm{B}$ & 4.93 & $16.25 \mathrm{~b}$ & $3.66 \mathrm{~b}$ & $152.92 \mathrm{C}$ & $73.02 \mathrm{~b}$ & $13.54 \mathrm{a}$ \\
$\mathrm{Cu}$ & 3.46 & $28.24 \mathrm{a}$ & $2.02 \mathrm{~d}$ & $183.89 \mathrm{C}$ & $95.32 \mathrm{~b}$ & $12.67 \mathrm{a}$ \\
$\mathrm{Fe}$ & 2.38 & $34.20 \mathrm{a}$ & $4.13 \mathrm{a}$ & $65.29 \mathrm{~d}$ & $179.85 \mathrm{a}$ & $17.18 \mathrm{a}$ \\
$\mathrm{Mn}$ & 4.20 & $33.17 \mathrm{a}$ & $4.62 \mathrm{a}$ & $307.08 \mathrm{~b}$ & $12.89 \mathrm{~b}$ & $12.85 \mathrm{a}$ \\
$\mathrm{Mo}$ & 3.25 & $33.67 \mathrm{a}$ & $3.16 \mathrm{c}$ & $422.55 \mathrm{a}$ & $69.91 \mathrm{~b}$ & $14.64 \mathrm{a}$ \\
$\mathrm{Zn}$ & 3.81 & $33.90 \mathrm{a}$ & $3.10 \mathrm{c}$ & $314.98 \mathrm{~b}$ & $68.15 \mathrm{~b}$ & $11.15 \mathrm{a}$ \\
$\mathrm{CV}(\%)$ & & 19.08 & 17.09 & 30.10 & 38.16 & 23.64 \\
\hline
\end{tabular}

Means followed by the same letter in the column do not differ by the Scott-Knott test at 0.05 probability level 
observed the same behavior between $\mathrm{K}$ and $\mathrm{Cu}$ for 'aroeirado-sertão'. In the present study, the omission of $\mathrm{N}$ in the nutrient solution caused reduction in the contents of $\mathrm{Fe}$ in the shoots (Table 4).

The increase in Mn contents and accumulation in the shoots of baru plants was observed in the treatment with omission of $\mathrm{Fe}$ (Tables 4 and 5). Jones Júnior et al. (1991) cite that there is a relation of antagonism between these nutrients.

The absorption of $\mathrm{Zn}$ was favored by the omission of $\mathrm{Mg}$ due to the occurrence of competitive inhibition. The plants of the complete treatment showed $\mathrm{Zn}$ contents of $14.14 \mathrm{mg}$ $\mathrm{kg}^{-1}$ and the highest content occurred in the treatment with omission of $\mathrm{Mg}$ (18.45 $\mathrm{mg} \mathrm{kg}^{-1}$ ). However, the content of this nutrient was not statistically different from those in the complete treatment and in the others (Table 5). Venturin et al. (1999) reported the effect of competitive inhibition between $\mathrm{Zn}$ and $\mathrm{Mg}$ in Peltophorum dubium plants.

Table 5. Dry matter production and accumulation of micronutrients in the shoots of Dipteryx alata plants under omission of macro and micronutrients

\begin{tabular}{|c|c|c|c|c|c|c|}
\hline \multirow{2}{*}{ Treatment } & \multirow{2}{*}{$\begin{array}{l}\text { Dry matter } \\
\text { (g) }\end{array}$} & \multicolumn{5}{|c|}{ Accumulation $\left(\mu \mathrm{g}\right.$ plant $\left.^{-1}\right)$} \\
\hline & & B & $\mathrm{Cu}$ & $\mathrm{Fe}$ & Mn & $\mathrm{Zn}$ \\
\hline Complete & 3.80 & $148.24 \mathrm{a}$ & $15.62 \mathrm{a}$ & $696.20 \mathrm{~b}$ & $332.20 \mathrm{a}$ & $53.73 \mathrm{a}$ \\
\hline $\mathrm{N}$ & 2.40 & $83.42 b$ & $5.42 \mathrm{~b}$ & $259.92 \mathrm{C}$ & $276.50 \mathrm{a}$ & $27.22 b$ \\
\hline$P$ & 3.37 & $98.10 b$ & $9.13 \mathrm{~b}$ & $620.59 \mathrm{~b}$ & $236.14 \mathrm{~b}$ & $39.46 \mathrm{~b}$ \\
\hline K & 1.97 & $56.91 \mathrm{~b}$ & $9.18 b$ & $441.65 \mathrm{c}$ & $144.89 \mathrm{~b}$ & $33.63 \mathrm{~b}$ \\
\hline $\mathrm{Ca}$ & 1.81 & $61.00 \mathrm{~b}$ & $6.72 \mathrm{~b}$ & $420.95 \mathrm{c}$ & $119.44 \mathrm{~b}$ & $28.51 \mathrm{~b}$ \\
\hline $\mathrm{Mg}$ & 3.05 & $100.10 \mathrm{~b}$ & $10.83 b$ & $647.79 \mathrm{~b}$ & $330.59 \mathrm{a}$ & $56.27 \mathrm{a}$ \\
\hline S & 4.15 & $143.51 \mathrm{a}$ & $14.03 \mathrm{a}$ & $802.53 \mathrm{~b}$ & $387.03 \mathrm{a}$ & $61.01 \mathrm{a}$ \\
\hline B & 4.93 & $80.11 b$ & $18.04 \mathrm{a}$ & $753.90 \mathrm{~b}$ & $359.99 \mathrm{a}$ & $66.75 \mathrm{a}$ \\
\hline $\mathrm{Cu}$ & 3.46 & $97.71 \mathrm{~b}$ & $6.99 \mathrm{~b}$ & $636.26 \mathrm{~b}$ & $329.81 \mathrm{a}$ & $43.84 \mathrm{~b}$ \\
\hline $\mathrm{Fe}$ & 2.38 & $81.40 \mathrm{~b}$ & $9.83 \mathrm{~b}$ & $155.39 \mathrm{c}$ & $428.04 \mathrm{a}$ & $40.89 b$ \\
\hline $\mathrm{Mn}$ & 4.20 & $139.31 \mathrm{a}$ & $19.40 \mathrm{a}$ & $1289.74 \mathrm{a}$ & $54.14 \mathrm{~b}$ & $53.97 \mathrm{a}$ \\
\hline Mo & 3.25 & $109.43 b$ & $10.27 b$ & $1373.29 \mathrm{a}$ & $227.21 b$ & $47.58 \mathrm{a}$ \\
\hline $\mathrm{Zn}$ & 3.81 & $129.16 \mathrm{a}$ & $11.81 \mathrm{~b}$ & $1200.07 \mathrm{a}$ & $259.65 b$ & $42.48 \mathrm{~b}$ \\
\hline CV (\%) & & 33.13 & 31.16 & 40.22 & 47.54 & 32.47 \\
\hline
\end{tabular}

Means followed by the same letter in the column do not differ by the Scott-Knott test at 0.05 probability level

\section{Conclusions}

1. In general, the growth of baru seedlings, except for height, is influenced by the omission of nutrients in the nutrient solution.

2. The main limiting nutrients, numerically, for baru seedlings were $\mathrm{K}>\mathrm{Ca}>\mathrm{Mg}>\mathrm{Fe}>\mathrm{Mn}>\mathrm{Mo}$.

\section{ACKnowledgments}

To the Minas Gerais Research Support Foundation (FAPEMIG), for the financial support to the research and to the Coordination for the Improvement of Higher Education Personnel (CAPES), for granting the scholarship.

\section{Literature Cited}

Ajalla, A. C. A.; Volpe, E.; Vieira, M. do C.; Zarate, N. A. H. Produção de mudas de baru (Dipteryx alata Vog.) sob três níveis de sombreamento e quatro classes texturais de solo. Revista Brasileira de Fruticultura, v.34, p.888-896, 2012. http://dx.doi.org/10.1590/ S0100-29452012000300031
Aprígio, A.; Rezende, R.; Freitas, P. S. L. de; Costa, A. R. da; Souza, R. S. de. Teor de nitrato em alface hidropônica em função de vazões e períodos de pós-colheita. Revista Brasileira de Engenharia Agrícola e Ambiental, v.16, p.946-951, 2012. http://dx.doi. org/10.1590/S1415-43662012000900004

Aquino, L. A. de; Silva, F. D. B. da; Berger, P. G. Características agronômicas e o estado nutricional de cultivares de girassol irrigado. Revista Brasileira de Engenharia Agrícola e Ambiental, v.17, p.551-557, 2013. http://dx.doi.org/10.1590/S141543662013000500013

Carlos, L.; Venturin, N.; Macedo, R. L. G.; Higashikawa, E. M.; Garcia, M. B.; Farias, E. de S. Crescimento e nutrição mineral de mudas de pequi sob efeito da omissão de nutrientes. Revista Ciência Florestal, v.24, p.13-21, 2014.

Dantas Neto, J.; Maciel, J. L.; Alves, A. S.; Azevedo, C. A. V. de; Fernandes, P. D.; Lima, V. L. A. de. Teores de macronutrientes em folhas de goiabeira fertirrigadas com nitrogênio. Revista Brasileira de Engenharia Agrícola e Ambiental, v.17, p.962-968, 2013. http:// dx.doi.org/10.1590/S1415-43662013000900008

Davide, A. C.; Silva, E. A. A. da. Produção de sementes e mudas de espécies florestais. Lavras: UFLA, 2008. 175p.

Dickson, A.; Leaf, A.; Hosner, J. F. Quality appraisal of white spruce and white pine seedling stock in nurseries. Forestry Chronicle, v.36, p.10-13, 1960. http://dx.doi.org/10.5558/tfc36010-1

Epstein, E.; Bloom, A. J. Nutrição mineral de plantas: Princípios e perspectivas. 2.ed. Londrina: Planta, 2006. 403p.

Flumignan, D. L.; Adami, M.; Faria, R. T. de. Área foliar de folhas íntegras e danificadas de cafeeiro determinada por dimensões foliares e imagem digital. Coffee Science, v.3, p.1-6, 2008.

Ferreira, D. F. Sisvar: A computer statistical analysis system. Ciência e Agrotecnologia, v.35, p.1039-1042, 2011.

Hoagland, D. R.; Arnon, D. I. The water culture methods for growing plants without soil. Berkeley: University of California - The Colege of Agriculture, 1950. 32p. Agricultural Experiment Station. Circular, 347

Jones Júnior, J. B.; Wolf, B.; Mills, H. A. Plant analysis handbook: A practical sampling, preparation, analysis and interpretation guide. Athens: Micro-Macro Publishing, 1991. 213p.

Machado, A. F. L.; Ferreira, L. R.; Santos, L. D. T.; Ferreira, F. A.; Viana, R. G.; Machado, M. S.; Freitas, F. C. L. Eficiência fotossintética e uso da água em plantas de eucalipto pulverizadas com glyphosate. Planta Daninha, v.28, p.319-327, 2010. http://dx.doi.org/10.1590/ S0100-83582010000200011

Machado, K. da S.; Maltoni, K. L.; Santos, C. M.; Cassiolato, A. M. R. Resíduos orgânicos e fósforo como condicionantes de solo degradado e efeitos sobre o crescimento inicial de Dipteryx alata Vog. Revista Ciência Florestal, v.24, p.541-552, 2014. http://dx.doi. org/10.5902/1980509815728

Magalhães, R. M. A cadeia produtiva da amêndoa do baru (Dipteryx alata Vog.) no cerrado: Uma análise da sustentabilidade da sua exploração. Revista Ciência Florestal, v.24, p.665-676, 2014. http:// dx.doi.org/10.5902/1980509815723

Malavolta, E. Manual de nutrição mineral de plantas. São Paulo: Agronômica Ceres, 2006. 638p.

Marques, T. C. L. L. de S. e M.; Carvalho, J. G. de; Lacerda, M. P. C.; Mota, P. E. F. da. Crescimento inicial do paricá (Schizolobium amazonicum) sob omissão de nutrientes e de sódio em solução nutritiva. Revista Cerne, v.10, p.184-195, 2004. 
Marschner, H. Mineral nutrition of higher plants. 3.ed. London: Academic Press, 2012. 889p.

Martinotto, F.; Martinotto, C.; Coelho, M. F. B.; Azevedo, R. A. B.; Albuquerque, M. C. F. Sobrevivência e crescimento inicial de espécies arbóreas nativas do Cerrado em consórcio com mandioca. Revista Pesquisa Agropecuária Brasileira, v.47, p.2229, 2012. http://dx.doi.org/10.1590/S0100-204X2012000100004

Mendonça, A. V. R.; Nogueira, F. D.; Venturin, N.; Souza, J. S. Exigências nutricionais de Myracrodruon urundeuva Fr. All. (Aroeira do Sertão). Revista Cerne, v.5, p.65-75, 1999.

Ramos, M. J. M.; Monnerat, P. H.; Pinho, L. G. da R.; Silva, J. A. da. Deficiência de macronutrientes e de boro em abacaxizeiro 'imperial': Composição mineral. Revista Brasileira de Fruticultura, v.33, p.261-271, 2011. http://dx.doi.org/10.1590/S010029452011005000032

Rudek, A.; Garcia, F. A. de O.; Peres, F. S. B. Avalição da qualidade de mudas de eucalipto pela mensuração da área foliar com o uso de imagens digitais. Enciclopédia Biosfera, v.9, p.37753787, 2013.
Sorreano, M. C. M.; Malavolta, E.; Silva, D. H.; Cabral, C. P.; Rodrigues, R. R. Deficiência de micronutrientes em mudas de sangra d’água (Croton urucurana Baill.). Revista Cerne, v.14, p.126-132. 2008. Sorreano, M. C. M.; Malavolta, E.; Silva, D. H.; Cabral, C. P.; Rodrigues, R. R. Deficiência de macronutrientes em mudas de Sangra d'Água (Croton urucurana Baill.). Revista Cerne, v.17, p.347-352, 2011. http://dx.doi.org/10.1590/S0104-77602011000300008

Sorreano, M. C. M.; Rodrigues, R. R.; Boaretto, A. E. Guia de nutrição para espécies florestais nativas. São Paulo: Oficina de Textos, 2012. 254p.

Taiz, L.; Zeiger, E. Fisiologia vegetal. 5.ed. Porto Alegre: Artmed, 2013. 918p.

Venturin, N.; Duboc, E.; Vale, F. R. do; Davide, A. C. Adubação mineral do angico amarelo (Peltophorum dubium (Spreng.) Taub.). Pesquisa Agropecuária Brasileira, v.34, p.441-448, 1999. http:// dx.doi.org/10.1590/S0100-204X1999000300016

Venturin, N.; Souza, P. A.; Macedo, R. L. G.; Nogueira, F. D. Adubação mineral da candeia (Eremanhus erythropappus (DC.) McLeish). Revista Floresta, v.35, p.211-219, 2005. 